Original Research Paper

\title{
Bibliometric Measures of Research Output of Lower Middle Income Economies
}

\author{
${ }^{1}$ Eric Afful-Dadzie, ${ }^{2}$ Stephen Nabareseh and ${ }^{2}$ Petr Klimek \\ ${ }^{1}$ University of Ghana Business School, Department of Management Information Systems, University of Ghana, Ghana \\ ${ }^{2}$ Faculty of Management and Economics, Tomas Bata University, Mostni 5139, 760 01, Zlin - Czech Republic
}

\author{
Article history \\ Received: 17-10-2016 \\ Revised: 17-01-2017 \\ Accepted: 18-01-2017 \\ Corresponding Author: \\ Stephen Nabareseh \\ Faculty of Management and \\ Economics, Tomas Bata \\ University in Zlin, Mostni \\ 5139, 76001 Zlin, Czech \\ Republic \\ Tel: +420777317137 \\ Email: nabareseh@fame.utb.cz
}

\begin{abstract}
To understand the path of Lower Middle Income (LMIC) Economies towards economic stability as far as Science, Technology and Innovation are concerned; this paper conducts trend analysis of research output in science-based disciplines of the 55 countries in the LMIC bracket, grouped into the 6 continents of the world. Factors of interest across the six regions were (1) source of funding for scientific research output measured against percentage share of Gross domestic expenditure on R\&D (GERD), (2) R\&D share of GDP measured against three key determinants of growth in Science, Technology and Innovation (Services, value added (\% of GDP); Industry, value added (\% of GDP) and High technology exports (\% of manufactured exports), ) and (3) scientific research publications measured against the three determinants of growth in Science, Technology and Innovation. The results show that, in the period of 2000-2012, the combined performance of LMIC countries in the Oceania region were relatively higher in the Services, value added (\% of GDP) and High technology exports (\% of manufactured exports) than LMICs in other regions. South America's LMICs performed relatively better under Industry, value added (\% of GDP) than other LMICs. The study helps to understand whether investments made in scientific research in LMICs have corresponding effect on the production of Science, Technology and Innovation.
\end{abstract}

Keywords: Lower Middle, Income Countries (LMICs), Funding, Science, Technology, Innovation, Bibliometrics

\section{Introduction}

Theoretical differences still exist between researchers on the subject of level of investments to education and its corresponding effect on economic growth (Krueger and Lindahl, 2000; Glaeser et al., 2004; Carnoy, 2005; World Bank, 2014b; Psacharopoulos and Patrinos, 2004; Pritchett, 2001; Hanushek and Wößmann, 2007). However, irrespective of where one stands in the divide in terms of the argument for and against the human capital theory in education (Becker, 2009; Welch, 1975; Sweetland, 1996; Baptiste, 2001; Nelson and Phelps, 1966), there seems to be a general consensus that countries with high Research and Development (R\&D) share of GDP tend to achieve positive economic growth especially in Science, Technology and Innovation (Lederman and Maloney, 2003; Rodríguez-Pose and Crescenzi, 2008; De Ferranti, 2003; Chen and Dahlman, 2005). For instance, in the Organization for Economic Co- operation and Development (OECD) member countries, where many fall in the high income group according to the World Bank's economic classification, deliberate knowledge-driven research policies that accelerate the economy and introduce new technologies are given outmost priority (Şener and Sarıdoğan, 2011). As a result, OECD countries perform relatively high above the rest of the world in terms of key indicators such as services value added, (\% of GDP), industry value added (\% of GDP) and high technology exports (\% of manufactured exports). In contrast to OECD countries, the average R\&D share of GDP in Africa where most Lower Middle Income (LMIC) Economies exist remained under 0.5 per cent from 2000 to 2012 . Africa's average R\&D share of GDP posted no increase in the last decade from 1990 and 2000 where it also remained under $0.5 \%$ (The World Bank, 2014a; Kearney, 2009). In recent times, China, Brazil, Malaysia and India have often been cited as success stories of how well focused R\&D share of GDP could 
translate into economic growth (Álvarez and Marin, 2013) for emerging economies. These countries also keep performing in one of the key measures of innovation-patents (Khan and Dernis, 2006).

In developing economies, higher education is largely seen as a plausible escape route from poverty (Glewwe and Jacoby, 2004; Wai, 2014; Hartog and Oosterbeek, 1998). Powell and Snellman (2004) affirm this in their definition of a knowledge-based economy as when intellectual strength takes precedence over physical inputs and natural resources. In view of this, Ponomariov and Toivanen (2014) posit that for developing economies to match the successes of high income economies in science, technology and innovation, local capacities in higher education should be strengthened for scientific knowledge production. Daraio and Moed (2011; Salter and Martin, 2001) as cited in Mulyanto (2014) explain that scientific production do not only have long-term effects but also have short and medium term effects on the overall performance of an economy. This phenomenon is particularly evident in the Gulf States where there have been considerable investments into higher education (Weber, 2011) partly because of the fear of depletion of oil reserves in the near future. Another worthy mention as far as growth in science, technology and innovation is concerned is building local funding capacities to meet national development planning goals. This is important because the focus of foreign funding agencies may often not be the same as a national or institutional goal as far as developmental objectives are concerned. An analysis of funding agencies of scientific research output of lower middle income countries show a great disparity between what is funded locally and externally. In view of this, Ponomariov and Toivanen (2014), recommends that emerging economies shed off the tag of 'imitators' to 'innovators' by building strong domestic knowledge capacities to spur innovative activities. In the advancement of technology, the socio-economic development of countries is enhanced with innovation and availability of resources (Milenkovic et al., 2014; Dobrota et al., 2012; Confraria and Godinho, 2015).

This paper uses an exploratory trend analysis to unravel interestingness measures across lower middle income countries in the 6 continents of the world as far as research in science-based disciplines is concerned from year 2000 to 2012. The paper explored the percentage share of local and foreign funding agencies as far as scientific research output is concerned compared to the Gross domestic expenditure on R\&D (GERD). Other interestingness measures considered were comparison of scientific research output measured against three key determinants of growth in Science, Technology and Innovation. These indicators are value added to Services (\% of GDP), value added to Industry
(\% of GDP) and High technology exports (\% of manufactured exports). Lastly the paper explored the number of research output of LMICs against their corresponding number of citations.

\section{Lower Middle Income Countries (LMIC)}

Lower Middle-Income Countries (LMICs) sometimes referred simply to as developing economies often come under intense scrutiny from developmental partners and donor agencies. This is often because LMICs tend to receive wide ranging supports in the forms of developmental aid, Foreign Direct Investments (FDI) and other financial assistances. LMICs are also generally seen to exude hope of sustainable economic growth compared to low income countries. In view of this, there is the growing tendency to ensure that countries in the LMIC bracket are on the right path to sustainable growth (Holzmann et al., 2013; Jaumotte et al., 2013).

LMICs are part of the 2003 World Bank country income classification system that places world economies into groups of four. These are Low, Lower middle, Upper middle and High income groups. This widely used classification system is based on the Gross National Income (GNI) per capita of countries in a preceding year (World Bank, 2014b; Glennie, 2011). For example the 2014 classification defines a lower middle income country (LMIC) as one whose GNI falls between $\$ 1046$ and $\$ 4125$, an almost $1 \%$ change from 2013. In Table 1, the list of current lower middle income countries grouped into the six continents of the world is shown. Over the last decade, there has been a considerable improvement in the GDP per capita for most of the countries in the LMIC bracket as seen in Fig. 1 representing 155\% change from 2000-2014. Additionally, the decade has witnessed an exponential increase in lending to most of the LMIC economies (Presbitero and Zazzaro, 2010) for various purposes including education. In the same period, Foreign Direct Investments (FDI) in the LMICs has exponentially increased even though the 'BRICS' countries of Brazil, Russia, India, China and South Africa contributed much in this progress (Boulle and Chella, 2014; Gammeltoft, 2008). Such assistances have come from varied sources such as the World Bank, International Monetary Fund (IMF), OECD and a number of individual donor countries (Verbeke and Renard, 2011). To understand the commensurate effect such assistances to the LMICs could have on the growth of their economies, this paper explores among others the relationship between R\&D share of GDP and key indicators of growth in Science, Technology and Innovation. The paper also explores the percentage of local and foreign funding sources to scientific research in LMICs and compares the trend with their respective R\&D share of GDP. 


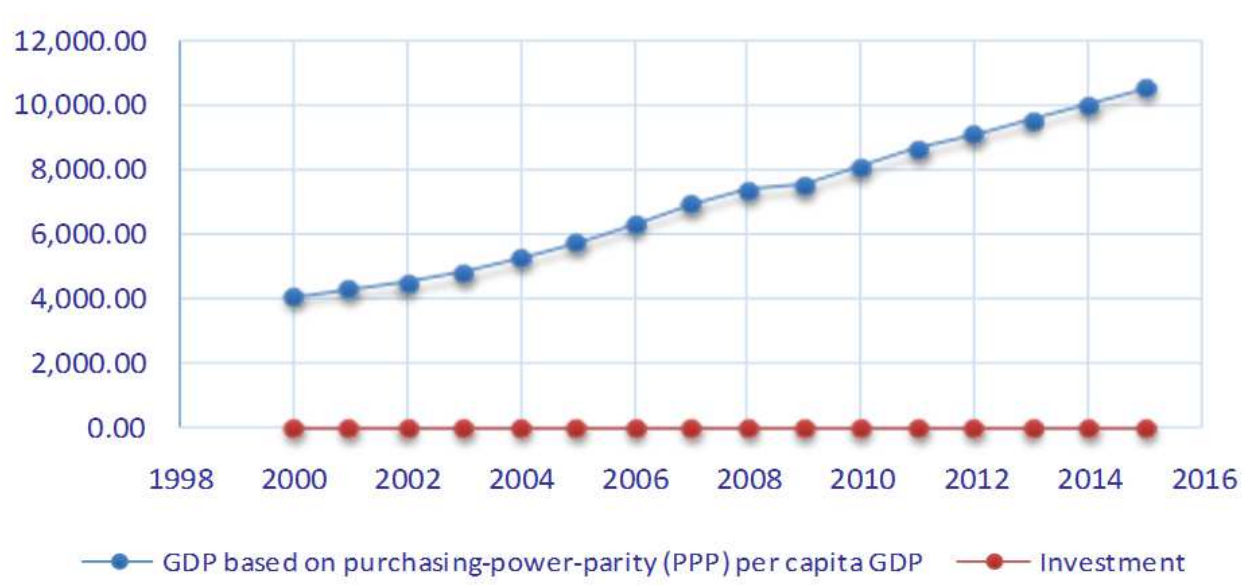

Fig. 1. Trend of GDP per PPP for emerging markets and developing economies from 2000-2013. Source: IMF, October 2014 World Economic Outlook Data

Table 1. Lower Middle Income Economies (LMICs)

\begin{tabular}{|c|c|c|c|c|c|c|c|}
\hline Africa & & Asia & & Europe & Oceania & South America & Americas \\
\hline Cameroon & Mauritania & Bhutan & Sri Lanka & Armenia & Kiribati & Bolivia & El Salvador \\
\hline Cabo Verde & São Tomé & Indonesia & Timor-Leste & Georgia & Micronesia, Fed. Sts & Guyana & Guatemala \\
\hline Congo, Rep. & Senegal & India & Uzbekistan & Kosovo & Papua New Guinea. & Paraguay & Honduras \\
\hline Côte d'Ivoire & South Sudan & Kyrgyz Rep & Vietnam & Moldova & Samoa & & Nicaragua \\
\hline Djibouti & Sudan & Lao PDR. & Yemen, Rep & Ukraine & Solomon Islands & & \\
\hline Egypt & Morocco & Mongolia & Syria & & Vanuatu & & \\
\hline Ghana & Nigeria & Pakistan & & & & & \\
\hline Lesotho & Zambia & Philippines & & & & & \\
\hline
\end{tabular}

In the same decade, public data available suggests that Research and Development (R\&D) share of GDP for most of the LMIC countries have crawled as compared to their counterpart in upper middle and high income economies (The World Bank, 2014a; Kearney, 2009). With a relatively low R\&D share of GDP but continued support in developmental aid to most of the LMICs including in education, this paper sets out to investigate the overall performance of LMICs key indicators of Science, Technology and Innovation growth. The paper is organized in the following sections. The methodology and research questions are outlined. Next, the results of the study and discussion are presented followed by conclusions of the study.

\section{Methodology}

The study collected data from diverse sources mainly the Web of Science (WoS), The World Bank, the National Science Foundation and the UNESCO Institute for Statistics (UIS). The period span for the study was between years 2000-2012 because of availability of corresponding data from the World Bank and UIS. The search term strategy for gathering the data on funding agencies was simply to extract the top funding agencies in each lower middle income country and aggregate them on a regional/continental level into either of local or foreign funding bodies. A thorough background check was done on each funding agency to correctly classify them under either local or foreign. A local or foreign funding agency is here defined based on the source of funding acknowledgement left on a published paper. Whiles not all sources of funding are revealed, most funding agencies require of beneficiaries to acknowledge them (funders) in their research publications. The research further assert that it is out of scope of this paper to determine whether the form of funding is full or partial.

The research also collected and analyzed data on the three key determinants of growth in Science, Technology and Innovation. These were Services, value added (\% of GDP), Industry, value added ( $\%$ of GDP) and High technology exports (\% of manufactured exports). Data on each determinant was extracted and analyzed for each lower middle income country and aggregated on a regional/continental level. Additionally, the research computed the mean growth as well as the Average Annual Growth Rate (AAGR) for each determinant on continental basis. This was used to track the trend of growth of Science, Technology and innovation for each lower middle income 'continent' over the period under study in relation to their average (R\&D) share of GDP. Finally, the number of publications and citations of each lower middle income country was also collected, analyzed and aggregated on a continental level. The 
lower middle income countries grouped into the various continents were then compared to understand the trend and unravel some interestingness measures.

On the collection and analysis especially of (R\&D) share of GDP, there were limited or no data on some of the countries in some of the years under our review. There were cases of these in all the six LMIC based continents. Notably, Oceania unfortunately had no public data for its (R\&D) share of GDP.

However, because the focus of the research was on the LMIC based 'continents' rather than on individual countries, the average cumulative effect figure of an LMIC continent for a particular year could not be overly affected.

\section{Research Questions}

Lower middle income countries, though a common group appears different in several aspects such as population size, number of institutions of higher learning and by extension, number of scientific researchers in each country and income level. To properly understand their progress as far as growth in science, technology and innovation are concerned; unbiased common datasets were collected guided by the following research questions:

1. What percentage share of LMICs scientific output is funded by local governments/organizations and foreign organizations?

2. Does reliance on foreign funding agencies explain the low percentage share of Gross domestic expenditure on R\&D (GERD) in Lower Middle Income Countries (LMICs)?

3. Does the trend of growth of R\&D share of GDP (GERD) in Lower Middle Income Countries (LMICs) have a relationship with the trend of growth of the three key indicators of growth in Science, Technology and Innovation; value added to Services (\% of GDP), value added to Industry ( $\%$ of GDP) and High technology exports (\% of manufactured exports)?

4. Does scientific output of a lower middle income country have a relationship with its $R \& D$ share of GDP (GERD)?

\section{Results and Discussion}

The findings in this study were generated guided by the research questions. The first research question sought to find by comparison, the percentage of Lower Middle Income Countries' scientific output funded by local and foreign governments/organizations. Using InCites ${ }^{\mathrm{TM}}$ analytics tool, the research grouped the top funding agencies into local and foreign for each country and aggregated it on the continental level for further comparison. In addition, the data extracted enabled us to determine the leading funding agencies for each of the six continents as seen in Table 3 .
In Fig. 2, it was realized that, $92 \%$ of the top 10 funding agencies in the LMICs are foreign. In Oceania for example, all the top 10 funding agencies of the lower middle income countries in the region were foreign. Asian countries in the LMIC bracket happen to have the highest local funding initiatives than the rest. Additionally, in absolute terms, Africa has the highest individual foreign agencies and organizations funding scientific research on the continent. In Table 3 , the leading funding agencies on the various continents are shown. For instance in Africa, the European Union seems to be the most dominant or leading supporter of scientific research activities followed by Bill And Melinda Gates Foundation and WELLCOME Trust in that order.

The number of local and foreign funding agencies in relation to R\&D share of GDP reveals some interesting trends. For example, whiles there are only 5 countries of lower middle income status in Europe compared to 16 and 14 in Africa and Asia respectively, the mean of R\&D share of GDP in Europe is almost $79.3 \%$ and $57.5 \%$ more than lower middle income countries in Africa and Asia respectively. The average annual R\&D share of GDP for lower middle income countries in Africa grew in the negative from 2000-2012. In the same period, the number of foreign funding agencies in LMICs in Africa kept growing. The picture is not different in LMICs in South America where R\&D share of GDP has crawled with an average annual growth also in the negatives as seen in Table 4. Similarly as in Africa, the number of foreign funding agencies for LMICs in South America far outweighs local funding sources. Whiles this pattern could be due to other factors other than over reliance on foreign funding to the neglect of local R\&D initiatives, it partially suggests that lower middle countries that proportionally have more foreign funding agencies tend to have very low R\&D share of GDP. Local funding initiatives for scientific work is therefore minimal in LMICs except for some countries in Asia.

The third research question sought to find by comparison whether the trend of R\&D share of GDP (GERD) of a lower middle income country has any relationship with the trend of growth in the three key indicators of growth in Science, Technology and Innovation. In Table 2, it is explained that High technology exports ( $\%$ of manufactured exports) are actually products that have direct bearing to well-focused executed R\&D programmes. To understand the pattern of growth, it is realized that though Africa has the highest number of LMICs, its paltry R\&D share of GDP figure seems to have a direct impact on its performance as far as High technology exports is concerned as shown in Table 4 and 5. The Americas LMIC region which has the lowest R\&D share of GDP surprisingly outperformed Africa in the high technology sector by $13.3 \%$. Asia's LMICs mean R\&D growth of 0.33 seems to have impacted positively on its yearly performances of high technology exports recording a 12.72 mean growth over the period. 


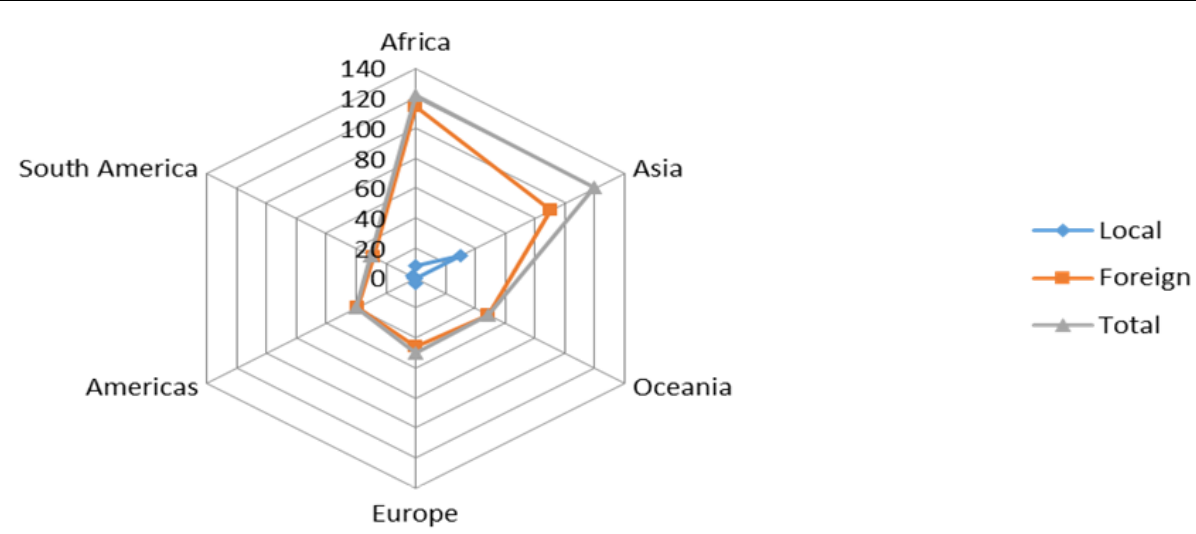

Fig. 2. Share of Local and Foreign funding agencies in the LMICs grouped into the six continents of the world

Table 2. Key determinants of science, technology and innovation

\begin{tabular}{ll}
\hline Services, etc., value added (\% of GDP) & $\begin{array}{l}\text { According to the World Bank, Services, etc., value added (\% of GDP) compose of } \\
\text { value added in the wholesale and retail trade sectors of a national economy. Such as } \\
\text { transport, tourism, government, financial, personal, real estate, professional, import } \\
\text { duties, bank service charges among others (World Bank, 2014). }\end{array}$ \\
The World Bank defines this category as comprising of value added in mining, \\
manufacturing, construction, electricity, water, and gas (World Bank, 2014).
\end{tabular}

Table 3. Leading funding agencies in lower middle income countries

\begin{tabular}{|c|c|}
\hline Continents & TOP funders in lower middle income countries \\
\hline \multirow[t]{6}{*}{ Africa } & European union \\
\hline & Bill and melinda gates foundation \\
\hline & WELLCOME trust \\
\hline & National institutes of health \\
\hline & European commission \\
\hline & Alexander von humboldt foundation \\
\hline \multirow[t]{6}{*}{ Asia } & Japan society for the promotion of science \\
\hline & WELLCOME trust \\
\hline & National science foundation \\
\hline & Ministry of education culture sports science and technology of japans \\
\hline & Swiss national science foundation \\
\hline & National institutes of health \\
\hline \multirow[t]{5}{*}{ Europe } & European Organization for Nuclear Research (CERN) \\
\hline & National science foundation China \\
\hline & National science foundation \\
\hline & National institutes of health \\
\hline & Russian foundation for basic research \\
\hline \multirow[t]{4}{*}{ South America } & Consejo nacional de investigaciones cientificas Y tecnicas \\
\hline & The Canadian International Development Agency (Cida) \\
\hline & National institutes of health \\
\hline & National science foundation \\
\hline \multirow[t]{5}{*}{ America } & National institutes of health \\
\hline & National Science Foundation \\
\hline & Network for research and training in tropical diseases in \\
\hline & Central America (Netropica) \\
\hline & Swedish international development cooperation agency (Sida) \\
\hline \multirow{6}{*}{ Oceania } & Australian research council \\
\hline & Australian government's international climate change adaptation initiative \\
\hline & WELLCOME trust \\
\hline & National institutes of health \\
\hline & National science foundation \\
\hline & European union \\
\hline
\end{tabular}


Table 4. Research and Development share of GDP of lower middle income countries aggregated on continental basis

\begin{tabular}{lllllllllllllll}
\hline & & & & & & & & & & & \multicolumn{3}{c}{$\begin{array}{l}\text { Mean } \\
\text { AAGR }\end{array}$} \\
& 2000 & 2001 & 2002 & 2003 & 2004 & 2005 & 2006 & 2007 & 2008 & 2009 & 2010 & 2011 & of share & $(\%)$ \\
\hline Africa & 0.33 & 0.54 & 0.25 & 0.27 & 0.22 & 0.17 & 0.33 & 0.24 & 0.28 & 0.13 & 0.51 & 0.17 & 0.29 & -0.06 \\
Asia & 0.24 & 0.28 & 0.25 & 0.33 & 0.35 & 0.36 & 0.35 & 0.4 & 0.37 & 0.36 & 0.35 & 0.39 & 0.33 & 0.05 \\
Europe & 0.45 & 0.51 & 0.48 & 0.52 & 0.51 & 0.54 & 0.6 & 0.53 & 0.54 & 0.58 & 0.54 & 0.51 & 0.52 & 0.01 \\
Oceania & - & - & - & - & - & - & - & - & - & - & - & - & - & - \\
South America & 0.29 & 0.18 & 0.19 & 0.07 & 0.07 & 0.07 & 0 & 0 & 0.05 & 0.16 & 0 & 0.05 & 0.13 & -0.16 \\
Americas & 0.04 & 0.04 & 0.04 & 0.04 & 0.04 & 0.04 & 0.05 & 0.08 & 0.09 & 0.07 & 0.06 & 0.04 & 0.05 & 0 \\
\hline
\end{tabular}

Table 5. High technology exports (\% of manufactured exports) of lower middle income countries grouped into continents

\begin{tabular}{|c|c|c|c|c|c|c|c|c|c|c|c|c|c|c|c|}
\hline & 2000 & 2001 & 2002 & 2003 & 2004 & 2005 & 2006 & 2007 & 2008 & 2009 & 2010 & 2011 & 2012 & $\begin{array}{l}\text { Mean of } \\
\text { share }\end{array}$ & $\begin{array}{l}\text { AAGR } \\
(\%)\end{array}$ \\
\hline Africa & 2.71 & 2.41 & 2.32 & 2.88 & 4.66 & 4.56 & 4.42 & 3.66 & 3.18 & 5.27 & 3.86 & 5.86 & 4.98 & 3.91 & 0.057 \\
\hline Asia & 18.11 & 15.34 & 14.25 & 13.39 & 14.7 & 13.15 & 12.93 & 12.95 & 10.66 & 11.32 & 9.45 & 9.13 & 10.03 & 12.72 & -0.052 \\
\hline Europe & 5.97 & 13.95 & 12.89 & 9.08 & 12.12 & 7.72 & 6.43 & 4.28 & 2.91 & 4.06 & 4.06 & 3.66 & 4.04 & 7.01 & -0.035 \\
\hline Oceania & 9.69 & 23.39 & 8.55 & 20.16 & 30.47 & 8.74 & 3.85 & 0.98 & 6.12 & 10.34 & 32.12 & 38.94 & 14.01 & 15.95 & 0.034 \\
\hline South America & 14.96 & 6.43 & 5.77 & 4.75 & 5.43 & 5.43 & 10.29 & 3.79 & 3.69 & 5.31 & 5.06 & 6.9 & 5.42 & 6.4 & -0.088 \\
\hline Americas & 4.19 & 3.92 & 5.25 & 4.48 & 4.94 & 4.79 & 4.08 & 3.48 & 3.12 & 4.09 & 5.43 & 5.1 & 4.75 & 4.43 & 0.011 \\
\hline
\end{tabular}

Table 6. Services, value added (\% of GDP) of lower middle income countries grouped into continents

\begin{tabular}{|c|c|c|c|c|c|c|c|c|c|c|c|c|c|c|c|}
\hline & 2000 & 2001 & 2002 & 2003 & 2004 & 2005 & 2006 & 2007 & 2008 & 2009 & 2010 & 2011 & 2012 & $\begin{array}{l}\text { Mean of } \\
\text { share }\end{array}$ & $\begin{array}{l}\text { AAGR } \\
(\%)\end{array}$ \\
\hline$\overline{\text { Africa }}$ & 50.81 & 49.74 & 50.1 & 50.55 & 50.79 & 51.23 & 52.02 & 52.68 & 49.86 & 50.88 & 53.48 & 52.61 & 51.08 & 51.22 & 0 \\
\hline Asia & 43.74 & 45.36 & 46.54 & 46.9 & 46.68 & 47.09 & 46.91 & 47.36 & 47.63 & 48.78 & 48.42 & 48.6 & 48.74 & 47.13 & 0.01 \\
\hline Europe & 46.76 & 47.44 & 48.42 & 48.85 & 51.08 & 52.92 & 57.49 & 59.09 & 61.14 & 63.66 & 62.27 & 61.4 & 61.99 & 55.58 & 0.026 \\
\hline Oceania & 54.1 & 56.64 & 55.41 & 54.37 & 55.06 & 63.55 & 64.21 & 64.91 & 64.43 & 64.63 & 64.38 & 63.06 & 63.15 & 60.61 & 0.014 \\
\hline South America & 47.86 & 47.88 & 46.99 & 46.99 & 46.81 & 48.23 & 48.25 & 47.82 & 45.97 & 48.03 & 47.71 & 47.28 & 48.15 & 47.54 & 0.001 \\
\hline Americas & 56.08 & 56.72 & 57.4 & 58.27 & 58.23 & 58.46 & 58.72 & 58.88 & 59.29 & 59.94 & 59.64 & 57.9 & 57.81 & 58.26 & 0.003 \\
\hline
\end{tabular}

Table 7. Industry, value added (\% of GDP) of lower middle income countries grouped into continents

\begin{tabular}{|c|c|c|c|c|c|c|c|c|c|c|c|c|c|c|c|}
\hline & 2000 & 2001 & 2002 & 2003 & 2004 & 2005 & 2006 & 2007 & 2008 & 2009 & 2010 & 2011 & 2012 & $\begin{array}{l}\text { Mean of } \\
\text { share }\end{array}$ & $\begin{array}{l}\text { AAGR } \\
(\%)\end{array}$ \\
\hline Africa & 29.79 & 28.72 & 27.96 & 27.91 & 29.57 & 31.06 & 32.82 & 32.85 & 35.21 & 33.23 & 34.6 & 36.66 & 34.33 & 31.9 & 0.013 \\
\hline Asia & 30.35 & 29.63 & 29.26 & 29.47 & 30.73 & 31.67 & 32.15 & 31.79 & 31.7 & 32 & 32.41 & 33.29 & 32.39 & 31.29 & 0.006 \\
\hline Europe & 27.88 & 27.43 & 28.21 & 29.35 & 28.14 & 28.17 & 28.15 & 29.93 & 28.34 & 25.08 & 25.91 & 25.8 & 25.75 & 27.55 & -0.007 \\
\hline Oceania & 18.93 & 18.46 & 17.54 & 17.41 & 17.2 & 12.22 & 11.75 & 11.64 & 11.53 & 12.24 & 14.3 & 15.9 & 18.88 & 15.23 & 0 \\
\hline South America & 31.5 & 32.03 & 32.79 & 31.3 & 30.84 & 28.92 & 31.75 & 32.68 & 32.91 & 33.06 & 33.48 & 33.41 & 33.58 & 32.17 & 0.006 \\
\hline Americas & 28.65 & 28.77 & 28.47 & 28.65 & 28.1 & 27.74 & 28.1 & 27.44 & 27.13 & 26.8 & 26.72 & 27.5 & 27.77 & 27.83 & -0.003 \\
\hline
\end{tabular}

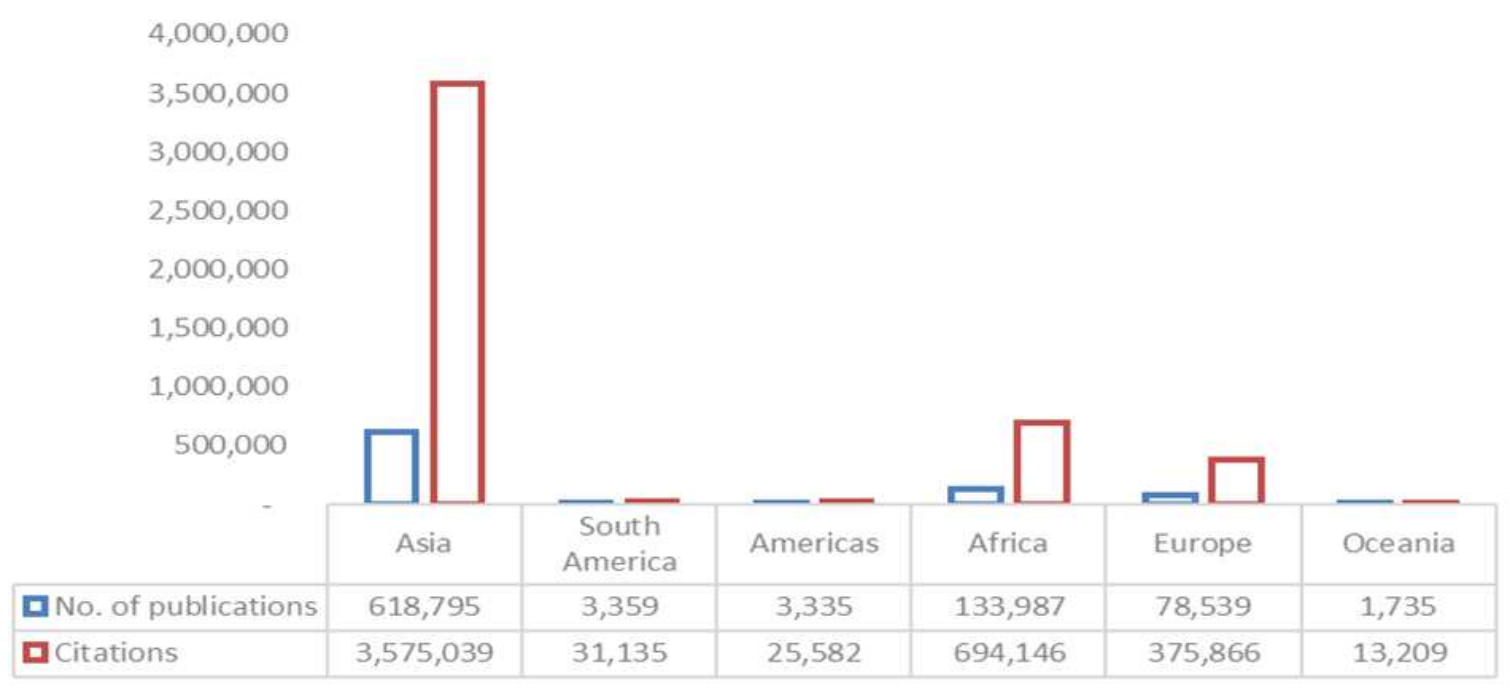

Fig. 3. Publications and citations in LMICs grouped into the six continents of the world 
LMICs in Europe which accounted for the highest R\&D share of GDP in the category managed a 7.01 (a negative annual average growth) mean growth compared to 15.95 by Oceania. The highest 'High technology exports (\% of manufactured exports)' came from Oceania which unfortunately had virtually no public data for its (R\&D) share of GDP.

In Table 6, the services sector shows Oceania again as the high performing LMIC continent followed by the Americas region which has the lowest R\&D share of GDP. In Table 7, LMICs in Oceania lag behind the rest of the regions in terms of performances in Industry, value added ( $\%$ of GDP).

In Table 7, LMICs in South America lead in terms of performances in Industry, value added though the continent's performances in the other indicators were not encouraging.

The fourth research question compares LMIC regional scientific output with R\&D share of GDP (GERD) to see if they depict a trend in the relationship. In Fig. 3, LMICs in the Asian region lead in the number of publications followed by Africa and Europe. This is however, expected given the relatively high number of researchers in the Asian region which also happen to have a relatively stronger R\&D share of GDP.

\section{Conclusion}

Lower Middle Income countries (LMICs) attract huge attention from development organizations that support them to attain economic stability. To understand how they are progressing in Science, Technology and Innovation, this paper looked at the trend of growth of LMICs based on their scientific contributions, R\&D share of GDP and their trend of growth in Science, Technology and Innovation. The research also explored sources of funding for scientific research work from these LMICs and their potential impact on Research and Development initiatives. The results indicated that a large majority of funding sources in lower middle income countries are foreign. This somehow explains the weakening trend in R\&D share of GDP in most of the LMICs especially in Africa and the Americas region. For example, Lesotho a lower middle income country currently has the world's lowest R\&D share of GDP of 0.01 whiles South Korea sits at the top with a towering $4.36 \%$ of GDP expenditure on research and development (World Bank 2014).

LMICs in Asia have the highest local scientific funding organizations which also partly explained their high growth rate in High Technology export-a key measure of growth in Science, Technology and Innovation. European lower middle income countries have the highest R\&D share of GDP; however, it rarely manifested itself in the three key determinants of growth in Science, Technology and Innovation. Asian lower middle income countries lead their counterparts in other continents in terms of scientific publications and their subsequent citations. However, this is partly expected because of their sheer numbers of researchers compared to the other LMIC 'continents' population size.

In all, the best performing Lower Middle Income 'continent' in the key indicators of growth in Science, Technology and Innovation (scoring high above the others in High technology exports and Services, value added of GDP) was Oceania even though there was no public data on their R\&D share of GDP to track the trend in their growth in the three key determinants of growth.

Authors accept that LMICs may have different focus areas/disciplines, number of researchers, population and other dynamics. However, the results will guide LMICs countries and other stakeholders to reorient their attention in on funding of $R \& D$ and draw their attention to outputs in the chosen disciplines. This paper helps to generally understand the trend of performances of Lower Middle Income Countries in Science-based research and their potential impact on their respective economies. Additionally, it helps to understand whether investments made in scientific research in LMICs have corresponding effect on the production of Science, Technology and Innovation.

\section{Acknowledgement}

This work was supported by Internal Grant Agency of Tomas Bata University under the project Nos. IGA/FaME/2016/019 and IGA/FaME/2015/023.

\section{Author's Contributions}

Eric Afful-Dadzie: Extraction of data from World Bank, analysis and write-up of introduction and results.

Stephen Nabareseh: Extraction of data from in Cites, analysis and write-up of methodology and conclusion.

Petr Klimek: In-depth review of paper, alignment and review of analytical part in line with research questions.

\section{Ethics}

None of the authors is in any conflict of interest position.

\section{References}

Álvarez, I. and R. Marin, 2013. FDI and technology as levering factors of competitiveness in developing countries. J. Int. Manage., 19: 232-246. DOI: 10.1016/j.intman.2013.02.005

Baptiste, I., 2001. Educating lone wolves: Pedagogical implications of human capital theory. Adult Educ. Q., 51: 184-201. DOI: 10.1177/074171360105100302 
Becker, G.S., 2009. Human Capital: A Theoretical and Empirical Analysis, with Special Reference to Education. 1st Edn., University of Chicago Press, Chicago, ISBN-10: 0226041220, pp: 412.

Boulle, L. and J. Chella, 2014. Joining the BRICs: The Case of South Africa. In: The Rise of the BRICS in the Global Political Economy: Changing Paradigms? Lo, V.I. and M. Hiscock (Eds.), Edward Elgar Publishing, Cheltenham, ISBN-10: 1782545476, pp: 99-122.

Carnoy, M., 2005. Education for All and the quality of education: A reanalysis. Stanford University.

Chen, D.H. and C.J. Dahlman, 2005. The knowledge economy, the KAM methodology and World Bank operations. World Bank Institute.

Confraria, H. and M.M. Godinho, 2015. The impact of African science: A bibliometric analysis. Scientometrics, 102: 1241-1268. DOI: $10.1007 / \mathrm{s} 11192-014-1463-8$

Daraio, C. and Moed, H.F., 2011. Is Italian science declining? Res. Policy, 40: 1380-1392. DOI: 10.1016/j.respol.2011.06.013

De Ferranti, D.M., 2003. Closing the Gap in Education and Technology. 1st Edn., World Bank Publications, Washington, DC, ISBN-10: 0821351729, pp: 216.

Dobrota, M., V. Jeremic and A. Markovic, 2012. A new perspective on the ICT development index. Inform. Develop., 28: 271-280. DOI: $10.1177 / 0266666912446497$

Gammeltoft, P., 2008. Emerging multinationals: Outward FDI from the BRICS countries. Int. J. Technol. Globalisat., 4: 5-22. DOI: 10.1504/IJTG.2008.016184

Glaeser, E.L., R. La Porta, F. Lopez-de-Silanes and A. Shleifer, 2004. Do institutions cause growth? J. Economic Growth, 9: 271-303. DOI: 10.1023/B:JOEG.0000038933.16398.ed

Glennie, J., 2011. The role of aid to middle-income countries: A contribution to evolving EU development policy.

Glewwe, P. and H.G. Jacoby, 2004. Economic growth and the demand for education: Is there a wealth effect? J. Develop. Econom., 74: 33-51. DOI: $10.1016 /$ j.jdeveco.2003.12.003

Hanushek, E.A. and L. Wößmann, 2007. The role of education quality for economic growth. World Bank, Washington, DC. DOI: 10.1596/1813-9450-4122

Hartog, J. and H. Oosterbeek, 1998. Health, wealth and happiness: Why pursue a higher education? Econom. Educ. Rev., 17: 245-256. DOI: $10.1016 / \mathrm{S} 0272-7757(97) 00064-2$

Holzmann, R., F. Mulaj and V. Perotti, 2013. Financial capability in low-and middle-income countries: Measurement and evaluation. CGAP.

Jaumotte, F., S. Lall and C. Papageorgiou, 2013. Rising income inequality: Technology, or trade and financial globalization. IMF Economic Rev., 61: 271-309. DOI: 10.1057/imfer.2013.7
Kearney, M.L., 2009. Higher education, research and innovation: Charting the course of the changing dynamics of the knowledge society. Higher education, research and innovation: Changing dynamics.

Khan, M. and H. Dernis, 2006. Global overview of innovative activities from the patent indicators perspective. OECD Publishing. DOI: $10.1787 / 18151965$

Krueger, A.B. and M. Lindahl, 2000. Education for growth: why and for whom? National Bureau of Economic Research. DOI: 10.2139/ssrn.223589

Lederman, D. and W.F. Maloney, 2003. R\&D and Development. 1st Edn., World Bank, Washington, D.C., pp: 37.

Milenkovic, N., J. Vukmirovic, M. Bulajic and Z. Radojicic, 2014. A multivariate approach in measuring socio-economic development of MENA countries. Economic Modell., 38: 604-608. DOI: 10.1016/j.econmod.2014.02.011

Mulyanto, 2014. Performance of Indonesian R\&D institutions: Influence of type of institutions and their funding source on R\&D productivity. Technol. Society, 38: 148-160. DOI: $10.1016 /$ j.techsoc.2014.04.003

Nelson, R.R. and E.S. Phelps, 1966. Investment in humans, technological diffusion and economic growth. Am. Economic Rev., 56: 69-75.

Ponomariov, B. and H. Toivanen, 2014. Knowledge flows and bases in emerging economy innovation systems: Brazilian research 2005-2009. Res. Policy, 43: 588-596. DOI: 10.1016/j.respol.2013.09.002

Powell, W.W. and K. Snellman, 2004. The knowledge economy. Ann. Rev. Sociol., 30: 199-220. DOI: 10.1146/annurev.soc.29.010202.100037

Presbitero, A.F. and A. Zazzaro, 2010. IMF lending in low-and middle-income countries in the wake of the global crisis. RELX Group logo. DOI: $10.2139 /$ ssrn. 1805005

Pritchett, L., 2001. Where has all the education gone? World Bank Econom. Rev., 15: 367-391. DOI: $10.1093 /$ wber/15.3.367

Psacharopoulos, G. and H.A. Patrinos, 2004. Returns to investment in education: A further update. Educ. Econom., 12: 111-134. DOI: $10.1080 / 0964529042000239140$

Rodríguez-Pose, A. and R. Crescenzi, 2008. Research and development, spillovers, innovation systems and the genesis of regional growth in Europe. Regional Stud., 42: 51-67. DOI: 10.1080/00343400701654186

Salter, A.J. and B.R. Martin, 2001. The economic benefits of publicly funded basic research: A critical review. Res. Policy, 30: 509-532. DOI: $10.1016 / \mathrm{S} 0048-7333(00) 00091-3$

Sandu, S. and B. Ciocanel, 2014. Impact of R\&D and innovation on high-tech export. Procedia Econom. Finance, 15: 80-90.

DOI: $10.1016 / \mathrm{S} 2212-5671(14) 00450-\mathrm{X}$ 
Şener, S. and E. Sarıdoğan, 2011. The effects of sciencetechnology-innovation on competitiveness and economic growth. Procedia-Social Behav. Sci., 24: 815-828. DOI: 10.1016/j.sbspro.2011.09.127

Sweetland, S.R., 1996. Human capital theory: Foundations of a field of inquiry. Rev. Educ. Res., 66: 341-359. DOI: 10.3102/00346543066003341

Verbeke, K. and R. Renard, 2011. Development cooperation with middle-income countries. Universiteit Antwerpen, Institute of Development Policy and Management (IOB).

Wai, J., 2014. Investigating the world's rich and powerful: Education, cognitive ability and sex differences. Intelligence, 46: 54-72.

DOI: 10.1016/j.intell.2014.05.002
Weber, A.S., 2011. The role of education in knowledge economies in developing countries. ProcediaSocial Behav. Sci., 15: 2589-2594. DOI: $10.1016 /$ j.sbspro.2011.04.151

Welch, F., 1975. Human capital theory: Education, discrimination and life cycles. Am. Econom. Rev., 65: 63-73.

The World Bank, 2014a. World Bank country and lending groups. The World Bank.

The World Bank, 2014b. Research and development expenditure ( $\%$ of GDP).

Xiong, J. and S. Qureshi, 2013. The quality measurement of china high-technology exports. Procedia Comput. Sci., 17: 290-297.

DOI: 10.1016/j.procs.2013.05.038 